\title{
Organometallic chemistry of chiral diphosphazane ligands: Synthesis and structural characterisation
}

\author{
KANNAN RAGHURAMAN, SWADHIN K MANDAL, \\ T S VENKATAKRISHNAN, SETHARAMPATTU S \\ KRISHNAMURTHY* and MUNIRATHINAM NETHAJI \\ Department of Inorganic and Physical Chemistry, Indian Institute of Science, \\ Bangalore 560 012, India \\ e-mail: sskrish@ipc.iisc.ernet.in
}

\begin{abstract}
The diphosphazane ligands of the type, $\left(\mathrm{C}_{20} \mathrm{H}_{12} \mathrm{O}_{2}\right) \mathrm{PN}(\mathrm{R}) \mathrm{P}(\mathrm{E}) \mathrm{Y}_{2}$ $\left(\mathrm{R}=\mathrm{CHMe}_{2}\right.$ or $(S)-* \mathrm{CHMePh} ; \mathrm{E}=$ lone pair or $\mathrm{S} ; \mathrm{Y}_{2}=\mathrm{O}_{2} \mathrm{C}_{20} \mathrm{H}_{12}$ or $\mathrm{Y}=\mathrm{OC}_{6} \mathrm{H}_{5}$ or $\mathrm{OC}_{6} \mathrm{H}_{4} \mathrm{Me}-4$ or $\mathrm{OC}_{6} \mathrm{H}_{4} \mathrm{OMe}-4$ or $\mathrm{OC}_{6} \mathrm{H}_{4} \mathrm{Bu}^{t}-4$ or $\mathrm{C}_{6} \mathrm{H}_{5}$ ) bearing axially chiral 1, $1^{\prime}$ binaphthyl-2,2'-dioxy moiety have been synthesised. The structure and absolute configuration of a diastereomeric palladium complex, $\left[\mathrm{PdCl}_{2}\left\{\eta^{2}-\left(\left(\mathrm{O}_{2} \mathrm{C}_{20} \mathrm{H}_{12}\right) \mathrm{PN}((S)\right.\right.\right.$ * $\left.\mathrm{CHMePh}) \mathrm{PPh}_{2}\right\}$ ] has been determined by $\mathrm{X}$-ray crystallography. The reactions of $\left[\mathrm{CpRu}\left(\mathrm{PPh}_{3}\right)_{2} \mathrm{Cl}\right]$ with various symmetrical and unsymmetrical diphosphazanes of the type, $\mathrm{X}_{2} \mathrm{PN}(\mathrm{R}) \mathrm{PYY}^{\prime}\left(\mathrm{R}=\mathrm{CHMe}_{2}\right.$ or $(S)-{ }^{*} \mathrm{CHMePh} ; \mathrm{X}=\mathrm{C}_{6} \mathrm{H}_{5}$ or $\mathrm{X}_{2}=\mathrm{O}_{2} \mathrm{C}_{20} \mathrm{H}_{12}$; $\mathrm{Y}=\mathrm{Y}^{\prime}=\mathrm{C}_{6} \mathrm{H}_{5}$ or $\mathrm{Y}=\mathrm{C}_{6} \mathrm{H}_{5}, \mathrm{Y}^{\prime}=\mathrm{OC}_{6} \mathrm{H}_{4} \mathrm{Me}-4$ or $\mathrm{OC}_{6} \mathrm{H}_{3} \mathrm{Me}_{2}-3,5$ or $\mathrm{N}_{2} \mathrm{C}_{3} \mathrm{HMe}_{2}-3,5$ ) yield several diastereomeric neutral or cationic half-sandwich ruthenium complexes which contain a stereogenic metal center. In one case, the absolute configuration of a trichiral ruthenium complex, viz. $\left[\mathrm{Cp} * \mathrm{Ru}\left\{\eta^{2}-\mathrm{Ph}_{2} \mathrm{PN}\left((S)-{ }^{*} \mathrm{CHMePh}\right) * \mathrm{PPh}\right.\right.$ $\left.\left.\left(\mathrm{N}_{2} \mathrm{C}_{3} \mathrm{HMe}_{2}-3,5\right)\right\} \mathrm{Cl}\right]$ is established by $\mathrm{X}$-ray diffraction. The reactions of $\mathrm{Ru}_{3}(\mathrm{CO})_{12}$ with the diphosphazanes $\left(\mathrm{C}_{20} \mathrm{H}_{12} \mathrm{O}_{2}\right) \mathrm{PN}(\mathrm{R}) \mathrm{PY}_{2}\left(\mathrm{R}=\mathrm{CHMe}\right.$ or $\mathrm{Me} ; \mathrm{Y}_{2}=\mathrm{O}_{2} \mathrm{C}_{20} \mathrm{H}_{12}$ or $\mathrm{Y}=\mathrm{OC}_{6} \mathrm{H}_{5}$ or $\mathrm{OC}_{6} \mathrm{H}_{4} \mathrm{Me}-4$ or $\mathrm{OC}_{6} \mathrm{H}_{4} \mathrm{OMe}-4$ or $\mathrm{OC}_{6} \mathrm{H}_{4} \mathrm{Bu}^{t}-4$ or $\mathrm{C}_{6} \mathrm{H}_{5}$ ) yield the triruthenium clusters $\left[\mathrm{Ru}_{3}(\mathrm{CO})_{10}\left\{\mu-\left(\mathrm{O}_{2} \mathrm{C}_{20} \mathrm{H}_{12}\right) \mathrm{PN}(\mathrm{R}) \mathrm{PY} \mathrm{Y}_{2}\right\}\right]$, in which the diphosphazane ligand bridges two metal centres. Palladium allyl chemistry of some of these chiral ligands has been investigated. The structures of isomeric $\eta^{3}$-allyl palladium complexes, $\left[\mathrm{Pd}\left(\eta^{3}-1,3-\mathrm{R}_{2}^{\prime}-\mathrm{C}_{3} \mathrm{H}_{3}\right)\left\{\eta^{2}-(\right.\right.$ rac $\left.\left.)-\left(\mathrm{O}_{2} \mathrm{C}_{20} \mathrm{H}_{12}\right) \mathrm{PN}\left(\mathrm{CHMe}_{2}\right) \mathrm{PY}_{2}\right\}\right]\left(\mathrm{PF}_{6}\right)$ $\left(\mathrm{R}^{\prime}=\mathrm{Me}\right.$ or $\mathrm{Ph} ; \mathrm{Y}=\mathrm{C}_{6} \mathrm{H}_{5}$ or $\left.\mathrm{OC}_{6} \mathrm{H}_{5}\right)$ have been elucidated by high field twodimensional NMR spectroscopic and X-ray crystallographic studies.
\end{abstract}

Keywords. Chiral phosphorus ligands; diphosphazanes; half-sandwich ruthenium complexes; chiral tri-ruthenium clusters; $\eta^{3}$-allyl palladium complexes.

\section{Introduction}

Diphosphazanes constitute a class of versatile short-bite bidentate P-donor ligands that have given rise to a varied and extensive transition metal organometallic chemistry. The organometallic chemistry of diphosphazane ligands with almost every transition metal in the periodic table is well documented ${ }^{1-3}$. A very attractive feature of diphosphazane ligands is that 'chirality' can be incorporated at the phosphorus centres as well as at the substituents attached to the nitrogen and the two phosphorus atoms. Furthermore, these ligand systems can be suitably modified thus providing an access to a range of mixed donor ligands. Heterofunctional diphosphazanes bearing P,O-, P,S- or P,N-

\footnotetext{
*For correspondence
} 
functionalities at one or both the phosphorus centers can be readily prepared. Interest in chiral diphosphazanes and their transition metal complexes has burgeoned recently ${ }^{4-6}$. As a part of our ongoing investigations on the organometallic chemistry of diphosphazane ligands ${ }^{7-11}$, herein we present a review of our recent work on the design and synthesis of several chiral diphosphazane ligands and their reactivity with various transition metal precursors. The synthesis and characterization of a new series of half-sandwich cyclopentadienyl ruthenium complexes and tri-ruthenium carbonyl clusters bearing chiral symmetrically and unsymmetrically substituted diphosphazanes are highlighted. In addition, results of highfield two-dimensional NMR studies on $\eta^{3}$-allyl-palladium complexes of chiral diphosphazanes are reported.

\section{Results and discussion}

\subsection{Synthesis of ligands}

Symmetrically substituted diphosphazane $(R R, S S)$ and $(S R, R S)-\left(\mathrm{C}_{20} \mathrm{H}_{12} \mathrm{O}_{2}\right) \mathrm{PN}(\mathrm{Me})$ $\mathrm{P}\left(\mathrm{O}_{2} \mathrm{C}_{20} \mathrm{H}_{12}\right)(\mathbf{1})$, bearing the axially chiral 1,1'-binaphthyl-2,2'-dioxy moiety, is prepared by the treatment of bis(dichlorophosphino)methylamine with two equivalents of racemic$1,1^{\prime}$-binaphthyl-2,2'-diol in the presence of a base such as triethylamine as shown in scheme 1. The ${ }^{31} \mathrm{P}\left\{{ }^{1} \mathrm{H}\right\}$ NMR spectrum of the reaction mixture reveals the presence of two diastereomers in 1.4:1 ratio. The diastereomers are assigned as a mixture of the racemic pair ( $R R$ and $S S$ ) and the meso pair ( $S R$ and $R S)$. Attempts to separate these diastereomers have so far been unsuccessful. However, the use of optically pure $1,1^{\prime}$ binaphthyl-2,2'-diol ( $R$ or $S$ ) has resulted in the synthesis of optically pure symmetrically substituted diphosphazane, $(R R$ or $S S)-\left(\mathrm{C}_{20} \mathrm{H}_{12} \mathrm{O}_{2}\right) \mathrm{PN}(\mathrm{Me}) \mathrm{P}\left(\mathrm{O}_{2} \mathrm{C}_{20} \mathrm{H}_{12}\right)$.

The unsymmetrical diphosphazanes, $(\mathrm{rac})-\left(\mathrm{C}_{20} \mathrm{H}_{12} \mathrm{O}_{2}\right) \mathrm{PN}\left(\mathrm{CHMe}_{2}\right) \mathrm{PY}_{2} \quad\left[\mathrm{Y}=\mathrm{OC}_{6} \mathrm{H}_{5}(\mathbf{2})\right.$, $\mathrm{OC}_{6} \mathrm{H}_{4} \mathrm{Me}-4(3), \mathrm{OC}_{6} \mathrm{H}_{4} \mathrm{OMe}-4(4)$, or $\left.\mathrm{OC}_{6} \mathrm{H}_{4} \mathrm{Bu}^{t}-4(5)\right]$ are prepared as shown in scheme 2. The reaction of racemic-[1,1'-binaphthyl]-2,2'-phosphorochloridite, $(\mathrm{rac})-\left(\mathrm{C}_{20} \mathrm{H}_{12} \mathrm{O}_{2}\right)$ $\mathrm{PCl}$ with three equivalents of $\mathrm{Pr}^{\mathrm{i}} \mathrm{NH}_{2}$ in toluene gives the amino derivative, (rac)$\left(\mathrm{C}_{20} \mathrm{H}_{12} \mathrm{O}_{2}\right) \mathrm{PNH}\left(\mathrm{CHMe}_{2}\right)$ which is treated with $\mathrm{PCl}_{3}$ in the presence of $\mathrm{NEt}_{3}$ to yield (rac) $-\left(\mathrm{C}_{20} \mathrm{H}_{12} \mathrm{O}_{2}\right) \mathrm{PN}\left(\mathrm{CHMe}_{2}\right) \mathrm{PCl}_{2}$. Subsequent derivatization with various phenols gives the unsymmetrically substituted diphosphazane ligands 2-5. The unsymmetrical diphosphazanes ( rac $)-\left(\mathrm{C}_{20} \mathrm{H}_{12} \mathrm{O}_{2}\right) \mathrm{PN}(\mathrm{R}) \mathrm{PPh}_{2}\left[\mathrm{R}=\mathrm{CHMe}_{2}(6)\right.$ or $\left.(S)-* \mathrm{CHMePh}(7)\right]$ have also been prepared by the reaction of the (amino)phosphane, $\mathrm{Ph}_{2} \mathrm{PNH}(\mathrm{R})$ with the racemic-[1,1'-binaphthyl]-2,2'-phosphorochloridite, ( rac $)-\left(\mathrm{C}_{20} \mathrm{H}_{12} \mathrm{O}_{2}\right) \mathrm{PCl}$ in the presence of $\mathrm{Et}_{3} \mathrm{~N}$ (scheme 3). The ligand 7 exists as a mixture of two diastereomers (SR and $S S$ ) in $1: 1$ ratio owing to the presence of a stereogenic center on the substituent attached to the nitrogen as revealed by its ${ }^{31} \mathrm{P}\left\{{ }^{1} \mathrm{H}\right\} \quad \mathrm{NMR}$ spectrum. The separation of these diastereomers by fractional crystallization was not successful. Since both the

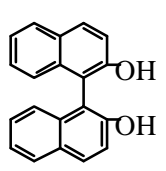

(i) Net3, toluene, $25^{\circ} \mathrm{C}, 18 \mathrm{~h}$

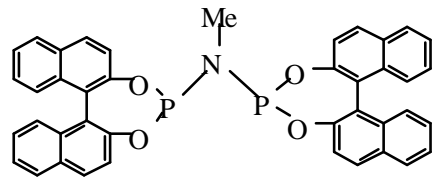

1

\section{Scheme 1.}




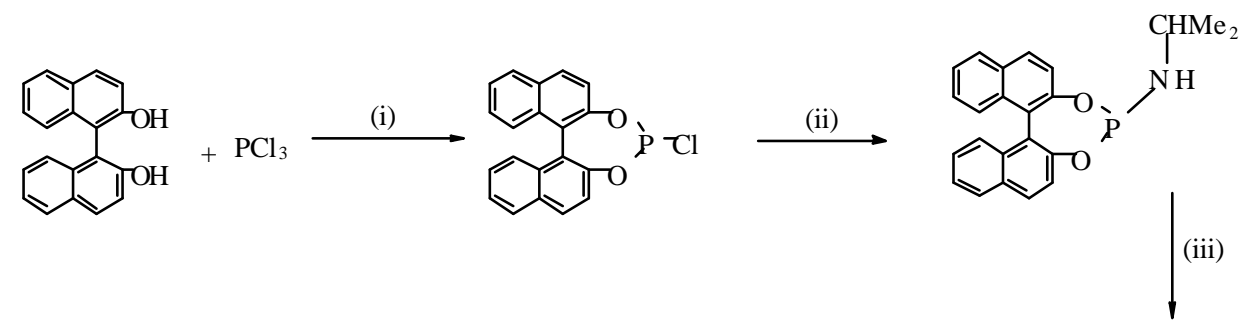

(i) $\mathrm{NEt}_{3}$, toluene, $14 \mathrm{~h}$

(ii) $\operatorname{Pr}^{\mathrm{i}} \mathrm{NH}_{2}$, toluene, $6 \mathrm{~h}$

(iii) $\mathrm{PCl}_{3}, \mathrm{NEt}_{3}$, toluene, $12 \mathrm{~h}$

(iv) $\mathrm{YH}, \mathrm{NEt}_{3}$, toluene, $12 \mathrm{~h}$

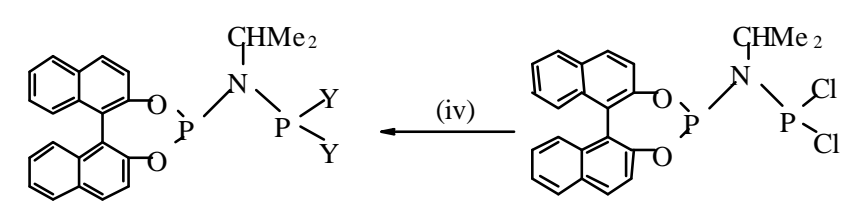

2; $\mathrm{Y}=\mathrm{OC}_{6} \mathrm{H}_{5}$

3; $\mathrm{Y}=\mathrm{OC}_{6} \mathrm{H}_{4} \mathrm{Me}-4$

4; $\mathrm{Y}=\mathrm{OC}_{6} \mathrm{H}_{4} \mathrm{OMe}-4$

5; $\mathrm{Y}=\mathrm{OC}_{6} \mathrm{H}_{4} \mathrm{Bu}^{\mathrm{t}}-4$

Scheme 2.

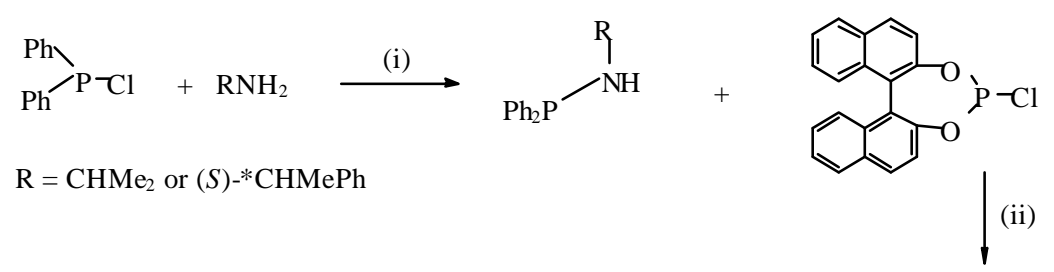

(i) $\mathrm{NEt}_{3}$, toluene, $6 \mathrm{~h}$

(ii) $\mathrm{NEt}_{3}$, toluene, $12 \mathrm{~h}$

(iii) $1 / 8 \mathrm{~S}_{8}$, benzene, $78^{\circ} \mathrm{C}, 2 \mathrm{~h}$

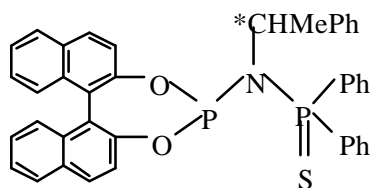

$(S R),(S S)-\mathbf{8 a}, \mathbf{8 b}$

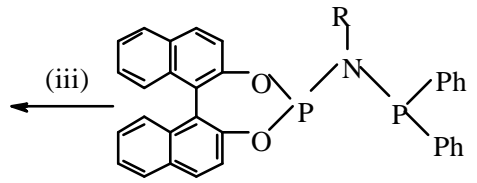

6; $\mathrm{R}=\mathrm{CHMe}_{2}$

7; $\mathrm{R}=(S)-* \mathrm{CHMePh}$

$(S R),(S S)-\mathbf{7 a}, \mathbf{7 b}$

Scheme 3.

diastereomers $\mathbf{7 a}$ and $\mathbf{7 b}$ did not show appreciable solubility difference in common organic solvents, attempts were made to separate the diastereomers by converting them to the corresponding monosulfides. A diastereomeric mixture of the diphosphazane monosulfides $\mathbf{8 a}$ and $\mathbf{8 b}$ is obtained by heating the diphosphazanes $\mathbf{7 a}$ and $\mathbf{7 b}$ with elemental sulfur (1:1/8) in boiling benzene (scheme 3). Oxidation to $\mathrm{P}=\mathrm{S}$ unit occurs only at the $-\mathrm{PPh}_{2}$ end as would be anticipated from the greater nucleophilicity of diphenyl 
substituted phosphorus compared to $-\mathrm{P}\left(\mathrm{O}_{2} \mathrm{C}_{20} \mathrm{H}_{12}\right)$ phosphorus. Attempts to separate these diastereomers (8a and $\mathbf{8 b}$ ) by fractional crystallization from various solvents have not been successful. The ligands $\mathbf{1 - 8}$ are characterized by ${ }^{1} \mathrm{H}$ and ${ }^{31} \mathrm{P}\left\{{ }^{1} \mathrm{H}\right\}$ NMR spectra and elemental analyses. The unsymmetrically substituted ligands $\mathbf{2}-\mathbf{8}$ show an AX pattern in their ${ }^{31} \mathrm{P}\left\{{ }^{1} \mathrm{H}\right\}$ NMR spectra.

\subsection{Synthesis of palladium complexes of (SR) and $(\mathrm{SS})-\left(\mathrm{C}_{20} \mathrm{H}_{12} \mathrm{O}_{2}\right) \mathrm{PN}((\mathrm{S})$ - *CHMePh)PPh (7)}

In an attempt to separate the diastereomers of the title diphosphazane ligand (7), a different approach has been attempted and this involves complexation with palladium. The reaction of $\left[\mathrm{PdCl}_{2}(\mathrm{COD})\right]$ with a diastereomeric mixture of $(S S)$ and $(S R)$ $\left(\mathrm{C}_{20} \mathrm{H}_{12} \mathrm{O}_{2}\right) \mathrm{PN}(\mathrm{R}) \mathrm{PPh}_{2} \quad(\mathrm{R}=(S)-* \mathrm{CHMePh}) \quad(7)$ at $25^{\circ} \mathrm{C}$ gives the diastereomeric complexes cis- $(S S)$ and $(S R)-\left[\mathrm{PdCl}_{2}\left\{\eta^{2}-\left(\mathrm{C}_{20} \mathrm{H}_{12} \mathrm{O}_{2}\right) \mathrm{PN}((S)-* C H M e P h) \mathrm{PPh}_{2}\right\}\right]$ (9a and 9b) (scheme 4). The formation of both the diastereomers is clearly evident from the ${ }^{31} \mathrm{P}\left\{{ }^{1} \mathrm{H}\right\}$ NMR spectrum of the reaction mixture. The separation of the diastereomers $9 \mathbf{a}$ and $\mathbf{9 b}$ can be achieved by selective crystallization from $\mathrm{CH}_{2} \mathrm{Cl}_{2} /$ petrol (1:1).

The $(S R)$-diastereomer 9a is isolated in a pure state. The other diastereomer $(S S)$ could not be obtained in a pure state. The $(S R)$-diastereomer (9a) has been characterised by elemental analysis, ${ }^{1} \mathrm{H}$ and ${ }^{31} \mathrm{P}\left\{{ }^{1} \mathrm{H}\right\}$ NMR spectroscopy and its structure determined by $\mathrm{X}$-ray crystallography. A perspective view of the molecule is shown in figure 1 . The absolute configuration of the chiral diphosphazane in the complex can be assigned by applying Cahn, Ingold and Prelog rules. The configuration at the chiral carbon is $S$ and based on this, the configuration of the binaphthyl skeleton can be assigned as $R$.

2.3 Reactions of $\left[\mathrm{CpRu}\left(\mathrm{PPh}_{3}\right)_{2} \mathrm{Cl}\right]$ with chiral diphosphazanes: Synthesis of chiral halfsandwich ruthenium complexes

The displacement of the two enantiotopic $\mathrm{PPh}_{3}$ ligands in $\left[\mathrm{CpRu}\left(\mathrm{PPh}_{3}\right)_{2} \mathrm{Cl}\right]$ by a chiral diphosphane would lead to chiral half-sandwich ruthenium complexes ${ }^{12}$. The reaction of a racemic unsymmetrical diphosphazane with $\left[\mathrm{CpRu}\left(\mathrm{PPh}_{3}\right)_{2} \mathrm{Cl}\right]$ may lead to the formation of two diastereomeric pairs, $\{(R R),(S S)\}$-racemic pair and $\{(S R),(R S)\}$-meso pair. The reaction of $\left[\mathrm{CpRu}\left(\mathrm{PPh}_{3}\right)_{2} \mathrm{Cl}\right]$ with the racemic diphosphazane, $(\mathrm{rac})-\left(\mathrm{H}_{12} \mathrm{C}_{20} \mathrm{O}_{2}\right) \mathrm{PN}$ $\left(\mathrm{CHMe}_{2}\right) \mathrm{PPh}_{2}$ in $1: 1$ molar proportions at $100^{\circ} \mathrm{C}$ for $5 \mathrm{~h}$ in toluene gives the complexes 10a-10e (scheme 5). Complex 10a may be either racemic or meso-diastereomer and is

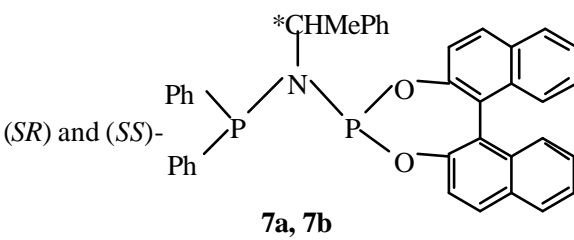

(i) $\left[\mathrm{PdCl}_{2}(\mathrm{COD})\right], \mathrm{CH}_{2} \mathrm{Cl}_{2}, 10 \mathrm{~min}$ (i)<smiles>[Y4][C](c1ccccc1)N1P2Oc3ccc4ccccc4c3-c3c(ccc4ccccc34)O[P]2(c2ccccc2)[P]1(Cl)Cl</smiles>

9a, 9b

Scheme 4. 


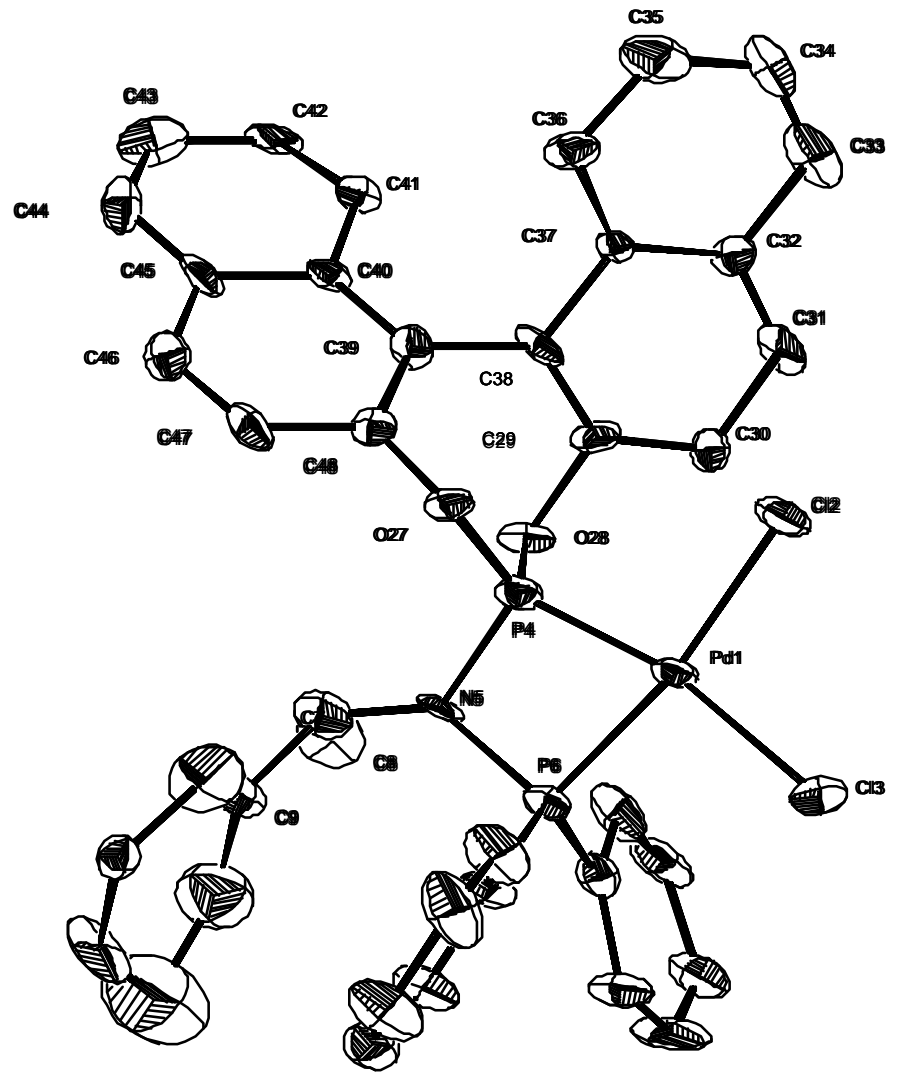

Figure 1. A view of the molecular structure of complex 9a. Hydrogen atoms have been omitted for clarity.

the major product. It is isolated in a pure state and characterized by elemental analysis, ${ }^{1} \mathrm{H}$ and ${ }^{31} \mathrm{P}\left\{{ }^{1} \mathrm{H}\right\}$ NMR spectroscopic studies. The ${ }^{31} \mathrm{P}\left\{{ }^{1} \mathrm{H}\right\}$ NMR spectrum of the mother liquor after removing complex 10a shows the presence of four other complexes (10b-10e) (scheme 5). These complexes (10b-10e) could not be isolated in a pure state owing to difficulties in their separation and also sensitivity of these complexes towards air and moisture. Nevertheless, the presence of these complexes is confirmed by the ${ }^{31} \mathrm{P}-{ }^{31} \mathrm{P}$ COSY spectrum of the mixture and their structures assigned on the basis of ${ }^{31} \mathrm{P}\left\{{ }^{1} \mathrm{H}\right\}$ NMR data.

The reactions of racemic unsymmetrical 'P-stereogenic' diphosphazanes of the type $\mathrm{X}_{2} \mathrm{PN}(\mathrm{R}) * \mathrm{PYY}^{\prime}$ with $\left[\mathrm{CpRu}\left(\mathrm{PPh}_{3}\right)_{2} \mathrm{Cl}\right]$ have been investigated (scheme 6). In these reactions, the steric bulk at the chiral phosphorus is varied; substituents $\mathrm{R}, \mathrm{X}$ and $\mathrm{Y}$ are kept constant $\left(\mathrm{R}=\mathrm{CHMe}_{2}, \quad \mathrm{X}=\mathrm{Y}=\mathrm{Ph}\right)$ while $\mathrm{Y}^{\prime}$ is varied $\left(\mathrm{Y}^{\prime}=\mathrm{OC}_{6} \mathrm{H}_{4} \mathrm{Me}-4\right.$, $\mathrm{OC}_{6} \mathrm{H}_{3} \mathrm{Me}_{2}-3,5$ or $\left.\mathrm{N}_{2} \mathrm{C}_{3} \mathrm{HMe}_{2}-3,5\right)$. The reaction of $\mathrm{Ph}_{2} \mathrm{PN}\left(\mathrm{CHMe}_{2}\right) \mathrm{PPh}\left(\mathrm{OC}_{6} \mathrm{H}_{4} \mathrm{Me}-4\right)$ with $\left[\mathrm{CpRu}\left(\mathrm{PPh}_{3}\right)_{2} \mathrm{Cl}\right]$ in 1:1 molar proportion gives two diastereomeric cationic complexes (racemic and meso) $\left[\mathrm{Cp} * \mathrm{Ru}\left\{\eta^{2}-\mathrm{Ph}_{2} \mathrm{PN}\left(\mathrm{CHMe}_{2}\right) * \mathrm{PPh}\left(\mathrm{OC}_{6} \mathrm{H}_{4} \mathrm{Me}-4\right)\right\} \mathrm{PPh}_{3}\right] \mathrm{Cl}$ (11a and 11b) in the ratio 1.5:1. The major diastereomer 11a (meso or racemic) has been isolated in a pure form as a yellow crystalline solid, whereas the minor diastereomer $\mathbf{1 1 b}$ 
(meso or racemic) is obtained only as an oily liquid. The ${ }^{31} \mathrm{P}\left\{{ }^{1} \mathrm{H}\right\}$ NMR spectrum of the mixture confirms the presence of two diastereomers; it shows two AMX patterns corresponding to two diastereomeric complexes 11a and 11b. The reactions of diphosphazanes bearing a slightly more bulky substituent on the chiral phosphorus atom, $\mathrm{Ph}_{2} \mathrm{PN}\left(\mathrm{CHMe}_{2}\right) * \mathrm{PPh}\left(\mathrm{OC}_{6} \mathrm{H}_{3} \mathrm{Me}_{2}-3,5\right) \quad$ or $\mathrm{Ph}_{2} \mathrm{PN}\left(\mathrm{CHMe}_{2}\right) * \mathrm{PPh}\left(\mathrm{N}_{2} \mathrm{C}_{3} \mathrm{HMe}_{2}-3,5\right) \quad$ with $\left[\mathrm{CpRu}\left(\mathrm{PPh}_{3}\right)_{2} \mathrm{Cl}\right]$ give only a single pair of cationic ruthenium diphosphazane complexes, $\left[\mathrm{Cp} * \mathrm{Ru}\left\{\eta^{2}-\mathrm{Ph}_{2} \mathrm{PN}\left(\mathrm{CHMe}_{2}\right) * \mathrm{PPh}\left(\mathrm{OC}_{6} \mathrm{H}_{3} \mathrm{Me}_{2}-3,5\right)\right\} \mathrm{PPh}_{3}\right] \mathrm{Cl} \quad$ (12) or $\left[\mathrm{Cp} * \mathrm{Ru}\left\{\eta^{2}-\right.\right.$ $\left.\left.\mathrm{Ph}_{2} \mathrm{PN}\left(\mathrm{CHMe}_{2}\right) * \mathrm{PPh}\left(\mathrm{N}_{2} \mathrm{C}_{3} \mathrm{HMe}_{2}-3,5\right)\right\} \mathrm{PPh}_{3}\right] \mathrm{Cl}(\mathbf{1 3})$ respectively in good yields. In these cases, only one AMX pattern is observed in the ${ }^{31} \mathrm{P}\left\{{ }^{1} \mathrm{H}\right\}$ NMR spectra of the reaction mixtures. The reactivity difference observed among the above diphosphazane ligands can be attributed to the differing steric bulk of the substituent on the stereogenic<smiles>Cl[Te](Cl)(c1ccccc1)P(c1ccccc1)c1ccccc1</smiles>$$
\mathrm{Ph}_{3} \mathrm{P}
$$

(i) toluene, $100^{\circ} \mathrm{C}, 5 \mathrm{~h}$<smiles></smiles>

(i)

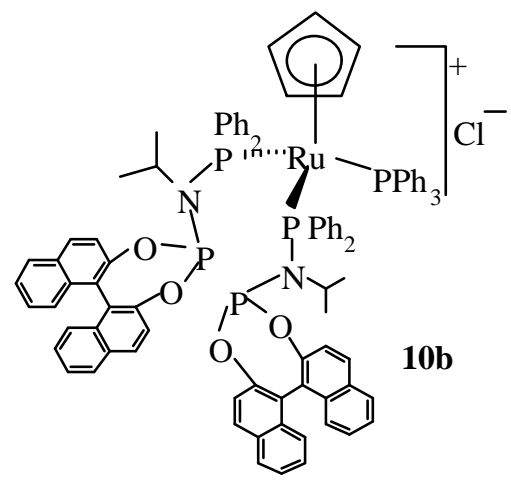

$$
\begin{array}{ccc}
\text { racemic } & \text { or } & \text { meso } \\
\left(R_{C} R_{\mathrm{Ru}}, S_{C} S_{\mathrm{Ru}}\right) & & \left(R_{C} S_{\mathrm{Ru}}, S_{C} R_{\mathrm{Ru}}\right)
\end{array}
$$

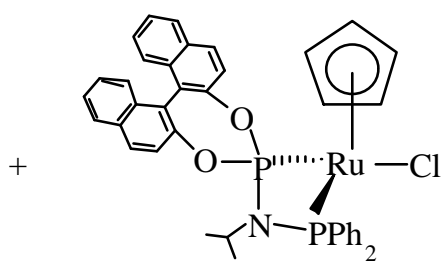

$10 \mathrm{c}, 10 \mathrm{~d}$

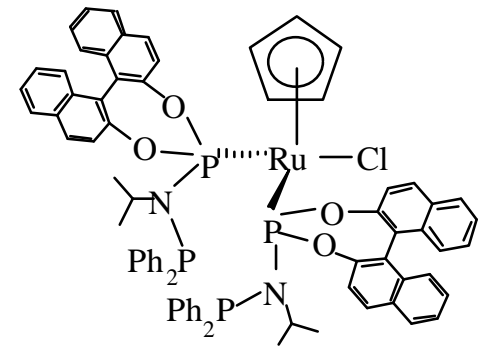

$10 \mathrm{e}$

$$
\underset{\left(R_{C} R_{\mathrm{Ru}}, S_{C} S_{\mathrm{Ru}}\right)}{\operatorname{racemic}} \text { and } \begin{gathered}
\text { meso } \\
\end{gathered}
$$

Scheme 5. 
<smiles>Cl[R](c1ccccc1)(c1ccccc1)[PH2](Cl)(c1ccccc1)c1ccccc1</smiles>

(i) Toluene, $110^{\circ} \mathrm{C}, 6 \mathrm{~h}$
$+$

(rac)-<smiles>[R]N(P)[PH2+]</smiles>

(i)

$+$

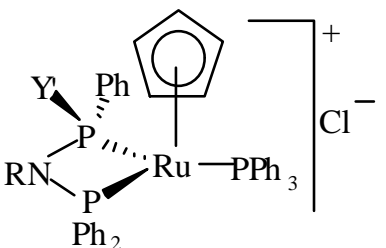

meso pair $S_{\mathrm{P}} R_{\mathrm{Ru}}$

11a; $\mathrm{Y}^{\prime}=\mathrm{OC}_{6} \mathrm{H}_{4} \mathrm{Me}-4$

12; $\mathrm{Y}^{\prime}=\mathrm{OC}_{6} \mathrm{H}_{3} \mathrm{Me}_{2}-3,5$

13; $\mathrm{Y}^{\prime}=\mathrm{N}_{2} \mathrm{C}_{3} \mathrm{HMe}_{2}-3,5$

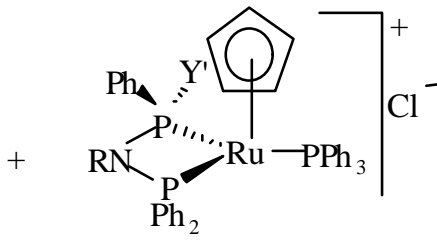
$R_{\mathrm{P}} R_{\mathrm{Ru}}$

(Assignments tentative)

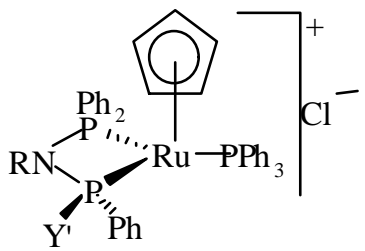
$S_{\mathrm{P}} S_{\mathrm{Ru}}$

11b; $\mathrm{Y}^{\prime}=\mathrm{OC}_{6} \mathrm{H}_{4} \mathrm{Me}-4$

Scheme 6.

phosphorus atom as the substituents on the nitrogen and the other phosphorus atom are not altered.

The reaction of a chiral symmetrical diphosphazane of the type $\mathrm{Ph}_{2} \mathrm{PN}((S)$ * $\mathrm{CHMePh}$ ) $\mathrm{PPh}_{2}$ (in which chirality resides at the substituent attached to nitrogen atom) with $\left[\mathrm{CpRu}\left(\mathrm{PPh}_{3}\right)_{2} \mathrm{Cl}\right]$ would give an optically active transition metal complex with the chirality at the back bone. The reaction of $\mathrm{Ph}_{2} \mathrm{PN}\left((S)-{ }^{*} \mathrm{CHMePh}\right) \mathrm{PPh}_{2}$ with $\left[\mathrm{CpRu}\left(\mathrm{PPh}_{3}\right)_{2} \mathrm{Cl}\right]$ in toluene at $100^{\circ} \mathrm{C}$ gives the neutral complex $\left[\mathrm{CpRu}\left\{\eta^{2}-\right.\right.$ $\left.\left.\mathrm{Ph}_{2} \mathrm{PN}(\mathrm{R}) \mathrm{PPh}_{2}\right\} \mathrm{Cl}\right]$ (14) and the cationic complex $\left[\mathrm{CpRu}\left\{\eta^{2}-\mathrm{Ph}_{2} \mathrm{PN}(\mathrm{R}) \mathrm{PPh}_{2}\right\} \mathrm{PPh}_{3}\right] \mathrm{Cl}$ (15) in 80 and 5\% yields respectively (scheme 7). The complexes $\mathbf{1 4}$ and $\mathbf{1 5}$ have been characterized by elemental analyses, ${ }^{1} \mathrm{H}$ and ${ }^{31} \mathrm{P}\left\{{ }^{1} \mathrm{H}\right\}$ NMR spectroscopic studies. The ${ }^{31} \mathrm{P}\left\{{ }^{1} \mathrm{H}\right\}$ NMR spectrum of the neutral complex 14 shows an AX pattern. The ${ }^{31} \mathrm{P}\left\{{ }^{1} \mathrm{H}\right\}$ NMR spectrum of the cationic complex 15 displays an AMX pattern. 
The reaction of an optically pure unsymmetrical diphosphazane of the type $\mathrm{X}_{2} \mathrm{PN}(* \mathrm{R}) * \mathrm{PYY}^{\prime}$ with $\left[\mathrm{CpRu}\left(\mathrm{PPh}_{3}\right)_{2} \mathrm{Cl}\right]$ would give diastereomeric half-sandwich ruthenium complexes with chirality at the metal. By this reaction, complexes containing three stereogenic centers can be synthesized (chirality at the metal is generated). The reaction of the optically pure diphosphazane, $(S R)-\mathrm{Ph}_{2} \mathrm{PN}((S)-* \mathrm{CHMePh}) * \mathrm{PPh}$ $\left(\mathrm{N}_{2} \mathrm{C}_{3} \mathrm{HMe}_{2}-3,5\right)^{6}$ with $\left[\mathrm{CpRu}\left(\mathrm{PPh}_{3}\right)_{2} \mathrm{Cl}\right]$ in toluene at $100^{\circ} \mathrm{C}$ gives the neutral chloro complex, $\left[\mathrm{Cp} * \mathrm{Ru}\left\{\eta^{2}-\mathrm{Ph}_{2} \mathrm{PN}((S)-* \mathrm{CHMePh}) * \mathrm{PPh}\left(\mathrm{N}_{2} \mathrm{C}_{3} \mathrm{HMe}_{2}-3,5\right)\right\} \mathrm{Cl}\right] \quad$ (16) and the cationic complex, $\left[\mathrm{Cp} * \mathrm{Ru}\left\{\eta^{2}-\mathrm{Ph}_{2} \mathrm{PN}((S)-* \mathrm{CHMePh}) * \mathrm{PPh}\left(\mathrm{N}_{2} \mathrm{C}_{3} \mathrm{HMe}_{2}-3,5\right)\right\} \mathrm{PPh}_{3}\right] \mathrm{Cl}$ (17) (scheme 8). The complex $\mathbf{1 6}$ has been isolated in a pure state from the reaction mixture by selective crystallization from toluene. The complex $\mathbf{1 7}$ could not be isolated in a pure form. The molecular structure and the absolute configuration of complex $\mathbf{1 6}$ are established by single crystal X-ray diffraction. The configuration of complex $\mathbf{1 6}$ is assigned as $S_{\mathrm{C}} S_{\mathrm{P}} R_{\mathrm{Ru}}$ ( $S$-at carbon, $S$-at phosphorus and $R$-at ruthenium) following the Cahn, Ingold, Prelog rules. The ${ }^{31} \mathrm{P}\left\{{ }^{1} \mathrm{H}\right\}$ NMR spectrum of complex 16 displays an $\mathrm{AX}$ pattern. The formation of the cationic complex 17 is inferred from the ${ }^{31} \mathrm{P}\left\{{ }^{1} \mathrm{H}\right\} \mathrm{NMR}$

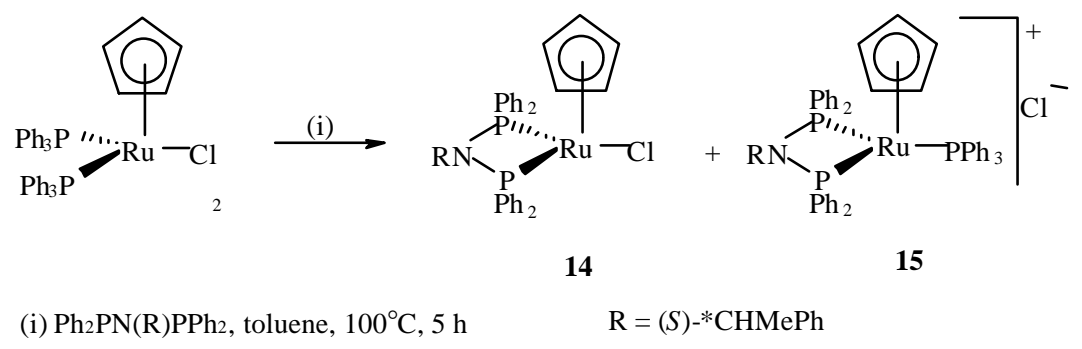

Scheme 7.<smiles>P[Te](Cl)(c1ccccc1)c1ccccc1</smiles>

(i) toluene, $105^{\circ} \mathrm{C}, 5 \mathrm{~h}$<smiles></smiles>

$$
\left(S_{\mathrm{C}} S_{\mathrm{P}} R_{\mathrm{Ru}}\right)
$$

16

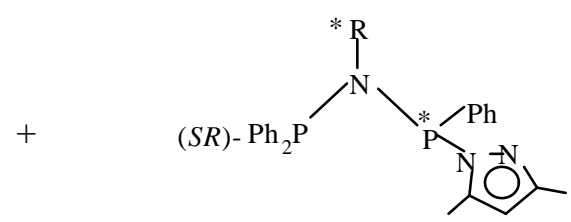

(i)

$(\mathrm{R}=(S)-* \mathrm{CHMePh})$

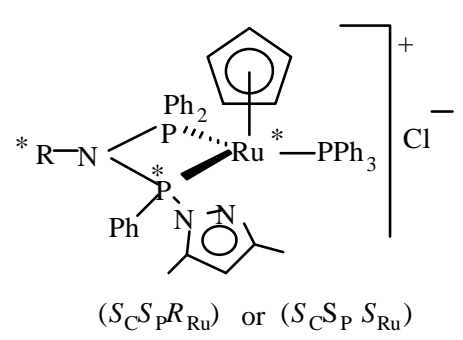

17

Scheme 8. 
spectrum of the reaction mixture; an AMX pattern is observed for 17. The absolute configuration of the cationic complex 17 can be either $S_{\mathrm{C}} S_{\mathrm{P}} R_{\mathrm{Ru}}$ or $S_{\mathrm{C}} S_{\mathrm{P}} S_{\mathrm{Ru}}$.

The reaction of a diastereomeric mixture of diphosphazanes $(S R)$ and $(S S)-\mathrm{Ph}_{2} \mathrm{PN}((S)$ $\left.{ }^{*} \mathrm{CHMePh}\right)^{*} \mathrm{PPh}\left(\mathrm{N}_{2} \mathrm{C}_{3} \mathrm{HMe}_{2}-3,5\right)^{6}$ with $\left[\mathrm{CpRu}\left(\mathrm{PPh}_{3}\right)_{2} \mathrm{Cl}\right]$ (scheme 9) gives three diastereomeric neutral chloro complexes $\left[\mathrm{Cp} * \mathrm{Ru}\left\{\eta^{2}-\mathrm{Ph}_{2} \mathrm{PN}((S)-* \mathrm{CHMePh}) * \mathrm{PPh}\right.\right.$ $\left.\left.\left(\mathrm{N}_{2} \mathrm{C}_{3} \mathrm{HMe}_{2}-3,5\right)\right\} \mathrm{Cl}\right] \quad\left(\mathbf{1 6}, \mathbf{1 8}\right.$ and 19) and two cationic complexes, [Cp*Ru$\left\{\eta^{2}-\right.$ $\left.\left.\mathrm{Ph}_{2} \mathrm{PN}((S)-* \mathrm{CHMePh}) * \mathrm{PPh}\left(\mathrm{N}_{2} \mathrm{C}_{3} \mathrm{HMe}_{2}-3,5\right)\right\} \mathrm{PPh}_{3}\right] \mathrm{Cl}(\mathbf{1 7}$ and 20). The formation of these complexes is identified only by ${ }^{31} \mathrm{P}\left\{{ }^{1} \mathrm{H}\right\}$ NMR spectrum. The neutral chloro complexes (16, 18 and 19) display an AX pattern and the cationic complexes (17 and 20) show an AMX pattern. The chloro complex $\mathbf{1 6}$ is formed by the complexation of $(S R)$ diastereomer of the diphosphazane to [CpRu] fragment and the complexes $\mathbf{1 8}$ and $\mathbf{1 9}$ are formed from the complexation of $(S S)$-diastereomer to $[\mathrm{CpRu}]$ fragment. The configuration of complexes 18 and 19 can be either $S_{\mathrm{C}} R_{\mathrm{P}} R_{\mathrm{Ru}}$ or $S_{\mathrm{C}} R_{\mathrm{P}} S_{\mathrm{Ru}}$. The absolute configuration at the phosphorus is likely to be ' $R$ ' in the complexes $\mathbf{1 8}$ and $\mathbf{1 9}$ as it is formed from the (SS)-diastereomer of the diphosphazane. The cationic complex $\mathbf{2 0}$ is also obtained from the complexation of $(S S)$-diastereomer of the diphosphazane and its absolute configuration would be either $S_{\mathrm{C}} R_{\mathrm{P}} R_{\mathrm{Ru}}$ or $S_{\mathrm{C}} R_{\mathrm{P}} S_{\mathrm{Ru}}$.

\subsection{Ruthenium carbonyl clusters of diphosphazane ligands}

There has been a great deal of interest in recent years on the synthesis of transition metal carbonyl clusters ${ }^{13}$, as they are valuable building blocks for cluster growth reactions. In particular, clusters bearing phosphanes as auxiliary ligands have been explored extensively in view of their rich chemistry and applications in catalysis. Studies in relation to the ruthenium cluster chemistry of chiral diphosphazanes are limited. The reactions of $\mathrm{Ru}_{3}(\mathrm{CO})_{12}$ with several diphosphazanes of the type $\mathrm{X}_{2} \mathrm{PN}(\mathrm{R}) \mathrm{PY}_{2}(\mathrm{R}=\mathrm{Et}$, $\mathrm{X}=\mathrm{Y}=\mathrm{Ph}$ or $\mathrm{OMe}$ or $\mathrm{OPr}^{\mathrm{i}}$ or $\mathrm{OPh} ; \mathrm{R}=\mathrm{Me}, \mathrm{X}=\mathrm{Y}=\mathrm{Et}$ ) have been investigated by

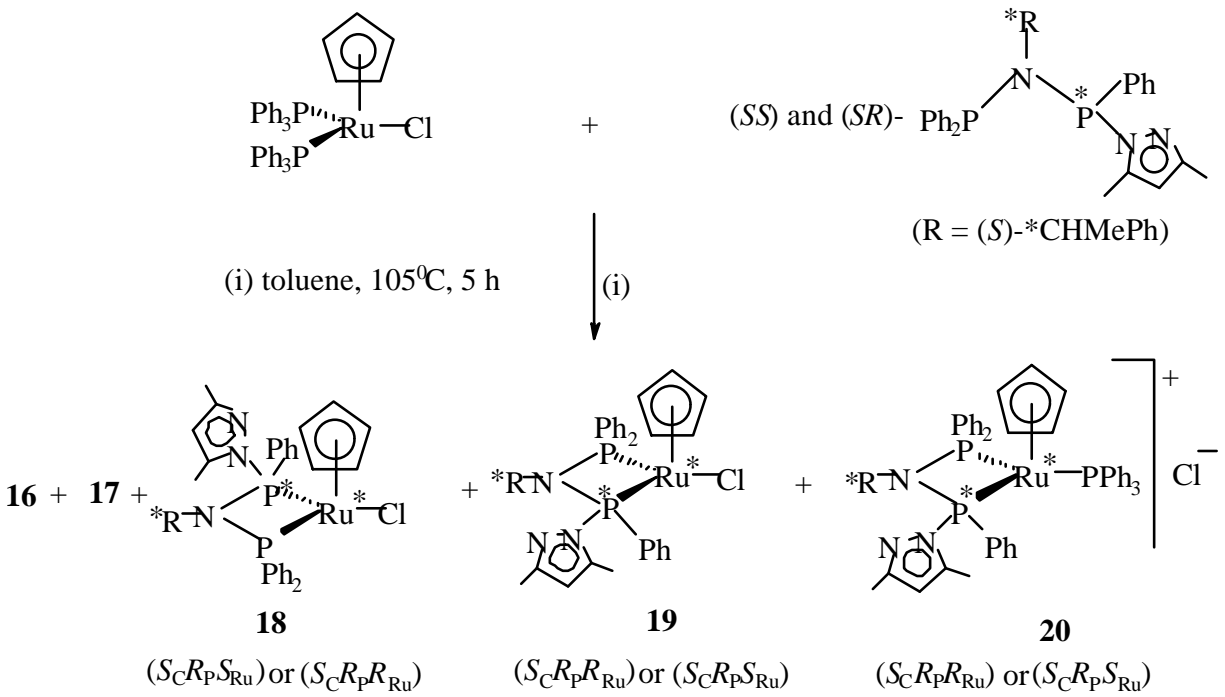

Scheme 9. 
Haines and coworkers and others ${ }^{1,14,15}$. Several di-nuclear, tri-nuclear and tetra-nuclear clusters have been isolated and structurally characterized. The main objective of the present study is to synthesize chiral ruthenium clusters derived from chiral diphosphazanes.

The benzophenone-ketyl radical initiated reaction of $\mathrm{Ru}_{3}(\mathrm{CO})_{12}$ with various diphosphazanes 1-6 in THF results in the substitution of two carbon monoxide ligands by a diphosphazane ligand as shown in scheme 10. The tri-ruthenium clusters 21-26 are characterized by NMR, IR spectroscopy and elemental analyses. The IR spectra of the clusters 21-26 show the CO stretching frequencies in the region $2085-1983 \mathrm{~cm}^{-1}$ which is indicative of terminal $\mathrm{CO}$ groups. The solid state structure of the cluster ( $\mathrm{rac}$ $\left[\mathrm{Ru}_{3}(\mathrm{CO})_{10}\left\{\boldsymbol{\mu}(\mathrm{rac})-\left(\mathrm{C}_{20} \mathrm{H}_{12} \mathrm{O}_{2}\right) \mathrm{PN}\left(\mathrm{CHMe}_{2}\right) \mathrm{P}(\mathrm{OPh})_{2}\right\}\right]$ (22) has been determined by $\mathrm{X}$-ray diffraction. A bridging mode of coordination of the $\mathrm{P}-\mathrm{N}-\mathrm{P}$ ligand is observed. The ruthenium atoms form a near equilateral triangle with bond angles close to $60^{\circ}$. The $\mathrm{P}-\mathrm{N}-\mathrm{P}$ bond angle is $117 \cdot 5^{\circ}$. Each of the two phosphorus atoms of the diphosphazane lie on either side of the equatorial plane formed by the three ruthenium centers. The $\mathrm{Ru}-\mathrm{Ru}$ bond lengths $(2.79-2.85 \AA)$ and $\mathrm{Ru}-\mathrm{C}$ bond lengths $(1.91-1.94 \AA)$ are in the range observed for similar type of complexes.

\section{$2.5 \eta^{3}$-Allyl palladium complexes of diphosphazanes}

The chemistry of $\eta^{3}$-allyl palladium(II) complexes is a topic of considerable contemporary interest in view of the various dynamic processes observed in these systems and also from its potential applications in asymmetric synthesis ${ }^{16,17}$. We have initiated a research program on the chemistry of $\eta^{3}$-allyl palladium complexes of diphosphazane ligands and as a part of this program, several $\eta^{3}$-allyl palladium complexes have been prepared and their structures and dynamic behavior in solution investigated.

Cationic $\eta^{3}$-allyl palladium complexes 27-29 have been synthesized in a straight forward manner by the treatment of the chlorodimer, $\left[\mathrm{Pd}_{2} \mathrm{Cl}_{2}\left(\eta^{3}-1,3-\mathrm{R}_{2}^{\prime}-\mathrm{C}_{3} \mathrm{H}_{3}\right)_{2}\right]$ $\left(\mathrm{R}^{\prime}=\mathrm{Me}\right.$ or $\left.\mathrm{Ph}\right)$ with the appropriate unsymmetrically substituted diphosphazane ligand (rac) $-\left(\mathrm{C}_{20} \mathrm{H}_{12} \mathrm{O}_{2}\right) \mathrm{PN}\left(\mathrm{CHMe}_{2}\right) \mathrm{PY}_{2}[\mathrm{Y}=\mathrm{OPh}(2)$ or $\mathrm{Y}=\mathrm{Ph}(6)]$ in the presence of $\mathrm{NH}_{4} \mathrm{PF}_{6}$ as shown in scheme 11. The ${ }^{31} \mathrm{P}\left\{{ }^{1} \mathrm{H}\right\}$ NMR spectra of these complexes reveal the

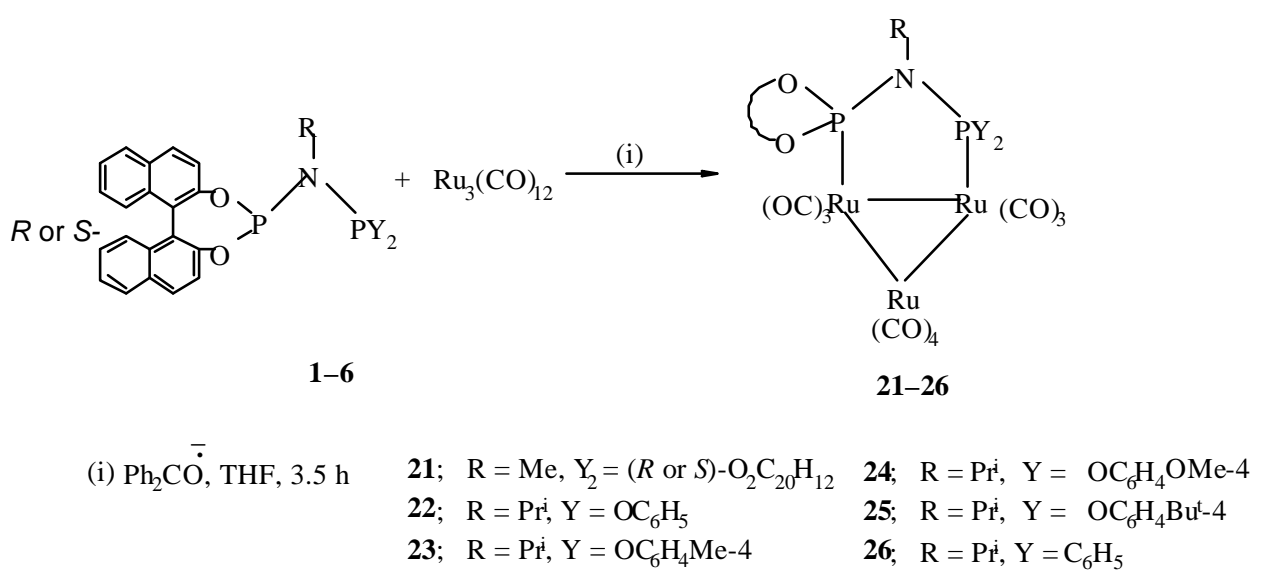

Scheme 10. 
presence of two isomers in solution; two AX spectra are observed in each case. The ${ }^{13} \mathrm{C}$ NMR spectra of these complexes (27-29) also indicate the presence of two isomers showing two sets of allyl ${ }^{13} \mathrm{C}$ resonances. The central allyl carbon resonance for the two isomers of 27-29 appears as two separate signals at $113 \cdot 0-121.8 \mathrm{ppm}$. The terminal allyl carbon resonances appear as doublet of doublets owing to coupling with the two different phosphorus nuclei present in the molecule. The terminal allyl carbon resonance trans to $-\mathrm{P}\left(\mathrm{O}_{2} \mathrm{C}_{20} \mathrm{H}_{12}\right)$ gives rise a signal at $89.8-96.4 \mathrm{ppm}$ for these isomers. The other terminal allyl carbon at the trans position with respect to the $-\mathrm{PY}_{2}(\mathrm{Y}=\mathrm{Ph}$ or $\mathrm{OPh})$ group resonates at $84 \cdot 0-90 \cdot 6 \mathrm{ppm}$.

The 1,3-disubstituted allyl complexes can exist in different allylic arrangements of the two substituents ( $\mathrm{Me}$ or $\mathrm{Ph}$ ) with respect to the central allyl proton $H_{c}$. The two substituents are syn with respect to the central allyl proton $H_{c}$ in the syn/syn-isomer whereas one of the substituents takes the anti position with respect to the central allyl proton $H_{c}$ in the syn/anti-isomer. It is also possible that isomers can arise from the different face coordination of the allyl moiety with the palladium centre thus forming different diastereomers in solution. We performed detailed two-dimensional NMR studies $\left({ }^{1} \mathrm{H}-{ }^{1} \mathrm{H}\right.$ DQF COSY, ${ }^{1} \mathrm{H}-{ }^{1} \mathrm{H}$ NOESY and ${ }^{1} \mathrm{H}-{ }^{1} \mathrm{H}$ ROESY $)$ to ascertain the allylic arrangement in these isomers and their structures in solution. The COSY experiment clearly shows that the minor isomer $27 \mathbf{b}$ contains two anti allylic protons at $3.93 \mathrm{ppm}$ $\left(H_{a}^{\prime}\right)$ and $4.09 \mathrm{ppm}\left(H_{a}\right)$ which are strongly coupled with the central allyl proton indicating that the two allyl methyl groups are situated in a syn position with respect to the central allyl proton $H_{c}$. For the major isomer 27a, the resonances of the allylic protons $H_{a}$ and $H_{a}{ }^{\prime}$ overlap with each other at $4.51 \mathrm{ppm}$ thus making their structural assignment difficult from the COSY spectrum. However, the ${ }^{1} \mathrm{H}-{ }^{1} \mathrm{H}$ NOESY spectrum unequivocally establishes a syn/syn-arrangement of two allyl methyl groups in the major isomer $\mathbf{2 7 a}$. The ${ }^{1} \mathrm{H}-{ }^{1} \mathrm{H}$ NOESY spectrum shows two strong cross-peaks arising from the central allyl proton $H_{c}$ to both the allyl-methyl protons in the isomer 27a and $27 \mathbf{b}$ supporting their syn/syn-allylic arrangements. The spectrum also shows an NOE contact between the $H^{\prime}{ }_{a}$ and $o$-phenyl proton(s) on the $-\mathrm{PPh}_{2}$ group for the major isomer 27a but no such NOE contact is observed for the minor isomer $\mathbf{2 7 b}$ (illustrated in figure 2).

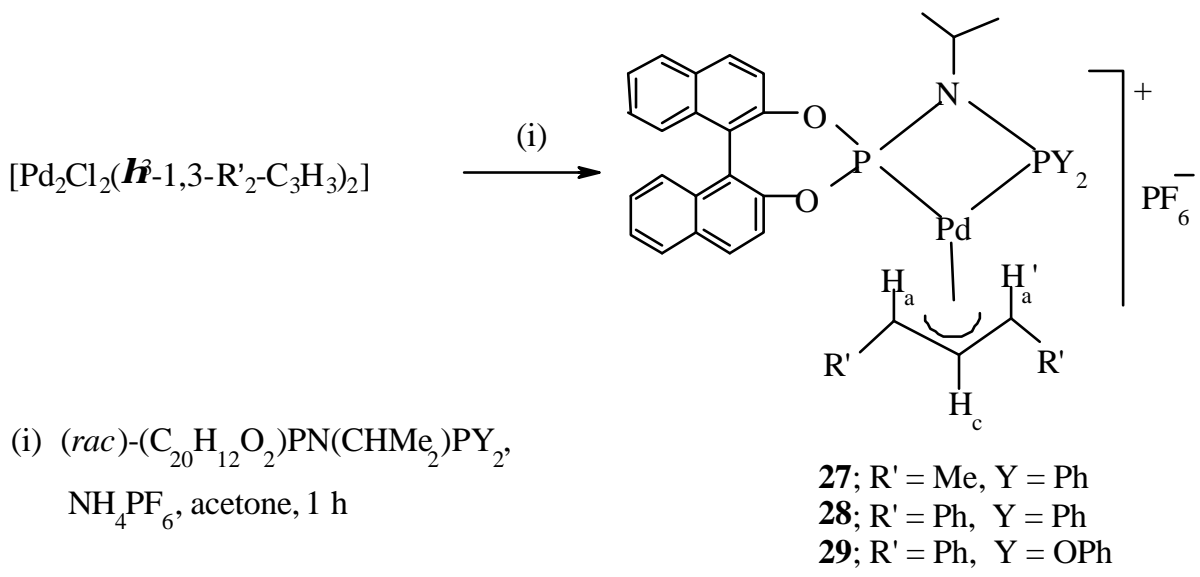

Scheme 11. 
On the basis of this observation, the two isomers are formulated as shown in figure 3. The isomers arise because of the different allyl face coordination to the palladium centre.

The 1,3-diphenyl-allyl complexes 28 and 29 exist as a mixture of two isomers in the ratio 8:1 as revealed by their ${ }^{31} \mathrm{P}\left\{{ }^{1} \mathrm{H}\right\}$ NMR spectra. The ${ }^{1} \mathrm{H}-{ }^{1} \mathrm{H}$ COSY spectrum suggests syn/syn-allylic arrangement in both the isomers of $\mathbf{2 8}$ and 29. The structures of these isomers in solution are determined by a careful analysis of the ${ }^{1} \mathrm{H}-{ }^{1} \mathrm{H}$ NOESY spectrum

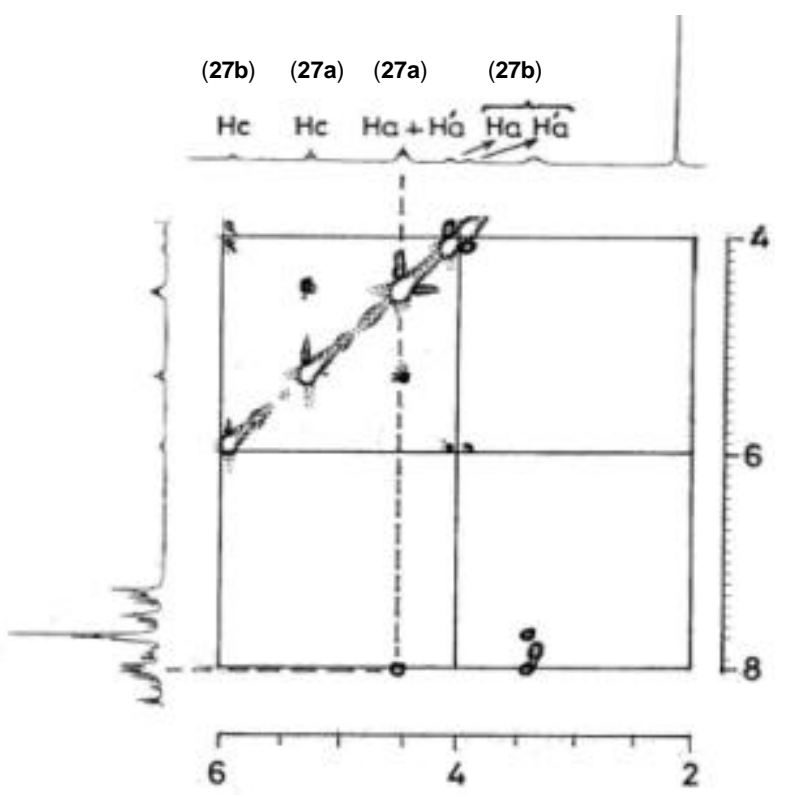

Figure 2. The ${ }^{1} \mathrm{H}-{ }^{1} \mathrm{H}$ NOESY $\left(400 \mathrm{MHz}, \mathrm{CDCl}_{3}\right)$ spectrum of $\left[\mathrm{Pd}\left(\eta^{3}-1,3-\mathrm{Me}_{2}-\right.\right.$ $\left.\left.\mathrm{C}_{3} \mathrm{H}_{3}\right)\left\{\eta^{2}-(\mathrm{rac})-\left(\mathrm{C}_{20} \mathrm{H}_{12} \mathrm{O}_{2}\right) \mathrm{PN}\left(\mathrm{CHMe}_{2}\right) \mathrm{PPh}_{2}\right\}\right]\left(\mathrm{PF}_{6}\right)(27)$; only part of the spectrum illustrated showing the selective NOE cross-peak between the $H_{a}^{\prime}$ proton and orthophenyl proton(s) of the $-\mathrm{PPh}_{2}$ group in $\mathbf{2 7 a}$.

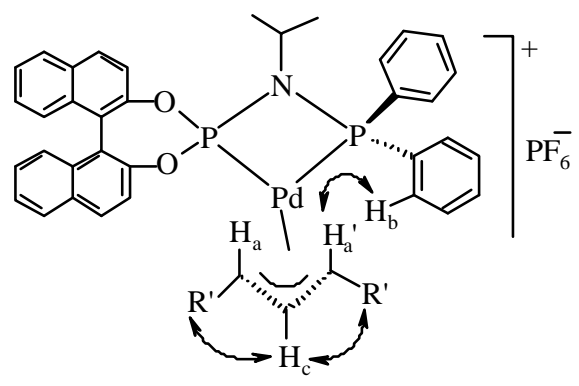

27a; $\mathrm{R}^{\prime}=\mathrm{Me}$ 28a; $\mathrm{R}^{\prime}=\mathrm{Ph}$

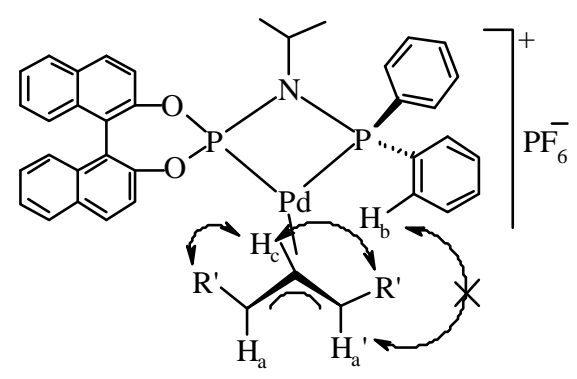

27b; $\mathrm{R}^{\prime}=\mathrm{Me}$ 28b; $\mathrm{R}^{\prime}=\mathrm{Ph}$

Figure 3. The two isomers of 1,3-disubstituted-allyl palladium complex, $\left[\operatorname{Pd}\left(\eta^{3}-1,3-\right.\right.$ $\left.\mathrm{R}_{2}^{\prime}{ }_{2} \mathrm{C}_{3} \mathrm{H}_{3}\right)\left\{\eta^{2}-(\right.$ rac $\left.\left.)-\left(\mathrm{C}_{20} \mathrm{H}_{12} \mathrm{O}_{2}\right) \mathrm{PN}\left(\mathrm{CHMe}_{2}\right) \mathrm{PPh}_{2}\right\}\right]\left(\mathrm{PF}_{6}\right)\left[\mathrm{R}^{\prime}=\mathrm{Me}(27)\right.$ or $\left.\mathrm{Ph}(\mathbf{2 8})\right]$ observed in solution. 
as described above for the structural elucidation of the two isomers of 27 . The ${ }^{1} \mathrm{H}-{ }^{1} \mathrm{H}$ NOESY spectrum displays a selective cross-peak between the anti allyl proton $H_{a}^{\prime}$ and $o$ phenyl proton(s) of the $-\mathrm{PPh}_{2}$ group for the major isomer 28a; for the minor isomer, $\mathbf{2 8 \mathbf { b }}$ no such NOE contact between $H_{a}^{\prime}$ and $o$-phenyl proton(s) of the $-\mathrm{PPh}_{2}$ group is observed. The two isomers arise because of the different allyl face coordination to the palladium centre. A crystallographic study has been carried for the complex $\mathbf{2 8}$. The solid state structure consists of only the major isomer $\mathbf{2 8 a ^ { 1 8 }}$. The geometry around palladium is distorted square-planar. The $\mathrm{P}(1)-\mathrm{Pd}(1)-\mathrm{P}(2)$ bond angle is 70.4 which deviates very much from the ideal value.

\section{Summary and outlook}

Simple and elegant methodologies have been developed for the synthesis of chiral and unsymmetrical diphosphazane ligands based on the $\mathrm{P}-\mathrm{N}-\mathrm{P}$ motif and bearing $1,1^{\prime}-$ binaphthyl-2,2'-dioxy moiety. The reactivity of these ligands towards late-transition metal complexes has been investigated and several chiral transition metal complexes have been isolated and structurally characterized. Various approaches for induction of chirality at a ruthenium metal center using chiral and unsymmetrically substituted diphosphazanes of the type, $\mathrm{X}_{2} \mathrm{PN}(\mathrm{R}) \mathrm{PYY}^{\prime}$ have been delineated and the absolute configuration of a novel trichiral metal complex viz. $\left[\mathrm{Cp} * \mathrm{Ru}\left(\eta^{2}-\mathrm{Ph}_{2} \mathrm{PN}((S)\right.\right.$ $\left.\left.{ }^{*} \mathrm{CHMePh}\right) * \mathrm{PPh}\left(\mathrm{N}_{2} \mathrm{C}_{3} \mathrm{HMe}_{2}-3,5\right) \mathrm{Cl}\right]$ has been established by X-ray crystallography. The utility of the chiral ligands to prepare tri-ruthenium carbonyl clusters has been demonstrated. These ligand systems also provide a convenient entry to $\eta^{3}$-allyl palladium chemistry. The structures and dynamics of $\eta^{3}$-allyl palladium complexes can be systematically probed by two-dimensional NMR techniques. The use of the chiral phosphorus ligands and their transition metal complexes in enantioselective catalysis is a topic of considerable contemporary interest and studies in this direction using chiral diphosphazane ligands will be rewarding.

\section{Acknowledgements}

We thank Department of Science and Technology (DST) and Council of Scientific and Industrial Research (CSIR), New Delhi for financial support. KR thanks the CSIR, New Delhi, for a fellowship.

\section{References}

1. Balakrishna M S, Reddy V S, Krishnamurthy S S, Nixon J F and Burckett St Laurent J C T R 1994 Coord. Chem. Rev. 1291

2. Witt M and Roesky H W 1994 Chem. Rev. 941163

3. Bhattacharyya P and Woollins J D 1995 Polyhedron 143367

4. Badía A, Navarro R and Urriolabeitia E P 1998 J. Organomet. Chem. 554105

5. Gimbert Y, Robert F, Durif A, Averbuch M-T, Kann N and Greene A E 1999 J. Org. Chem. 643492

6. Babu R P K, Krishnamurthy S S and Nethaji M 1995 Tetrahedron: Asymmetry 6427

7. Ganesan M, Krishnamurthy S S and Nethaji M 1998 J. Organomet. Chem. 570247

8. Ganesan M, Krishnamurthy S S, Nethaji M and Raghuraman K 1999 Phosphorus, Sulphur Silicon 147355

9. Babu R P K, Krishnamurthy S S and Nethaji M 1995 Organometallics 142047

10. Babu R P K, Krishnamurthy S S and Nethaji M 1993 J. Organomet. Chem. 454157 
11. Babu R P K, Aparna K, Krishnamurthy S S and Nethaji M 1995 Phosphorus, Sulphur Silicon 10339

12. Consiglio G and Morandini F 1987 Chem. Rev. 87761

13. Field J S, Haines R J and Ray J A 1989 J. Organomet. Chem. 377 C35

14. Engel D W, Moodley K G and Subramony L 1988 J. Organomet. Chem. 349393

15. Leeuw G D, Field J S, Haines R J, McCullooch B, Meintjies E, Kandasamy M C, Moodley G, Oliver G M, Sampson C M and Steen N D 1982 J. Organomet. Chem. 228 C66

16. Helmchen G and Pfaltz A 2000 Acc. Chem. Res. 33336

17. Trost B M and van Vranken D L 1996 Chem. Rev. 96395

18. Mandal S K, Krishnamurthy S S and Stalke D (unpublished results) 